\title{
Room-temperature silver-containing liquid metal salts with nitrate anions $\dagger$
}

\author{
Stijn Schaltin, ${ }^{a}$ Neil R. Brooks, ${ }^{b}$ Jeroen Sniekers, ${ }^{b}$ Daphne Depuydt, ${ }^{b}$ Luc Van Meervelt, ${ }^{b}$ Koen \\ Binnemans, ${ }^{b}$ Jan Fransaer ${ }^{a, *}$
}

\author{
Received Xth XXXXXXXXXX 20XX, Accepted Xth XXXXXXXXX 20XX \\ First published on the web Xth $X X X X X X X X X X 200 X$ \\ DOI: 10.1039/b000000x
}

The synthesis, structural, thermal and electrochemical properties properties of fluorine-free silver-containing ionic liquids are presented. The ionic liquid cations are formed by a silver(I) ion surrounded by two 1-alkylimidazole ligands, with the counter anions being nitrate ions. Depending on the alkyl chain length, the complexes were found to be liquids at room temperature or melting slightly above this. For the solid compounds it was possible to elucidate the structure by single crystal X-ray analysis. The ionic liquids are electroactive, have good mass transport properties and can be used for the electrodeposition of silver at high current densities. The thermal properties and stability of these compounds were tested by differential scanning calorimetry and thermogravimetrical analysis. The viscosity of the ionic liquids follows a Vogel-Tamman-Fulcher relationship as function of temperature. The electrochemical properties of the complexes were tested by cyclic voltammetry and the resulting electrodeposits were examined by scanning electron microscopy and atomic force microscopy.

\section{Introduction}

Ionic liquids are gaining importance in applications such as electrolytes in batteries and supercapacitors, in photovoltaic devices, and for the electrodeposition of metals due to their wide electrochemical window and the presence of intrinsic ionic charge carriers. ${ }^{1-3}$ A good mass transfer is crucial in these applications but, as the viscosity of most ionic liquids is quite high compared to molecular solvents, the mass transport in ionic liquids is often rather poor. Most simple inorganic salts (e.g. chlorides and sulphates) are poorly soluble in ionic liquids with weakly coordinating anions, such as $\left[\mathrm{BF}_{4}\right]^{-}$, $\left[\mathrm{PF}_{6}\right]^{-}$or bis(trifluoromethylsulfonyl)imide $\left(\left[\left(\mathrm{CF}_{3} \mathrm{SO}_{2}\right)_{2} \mathrm{~N}\right]^{-}\right.$ or $\left.\left[\mathrm{Tf}_{2} \mathrm{~N}\right]^{-}\right)$. Ionic liquids with dicyanamide anions are an exception, because they can solubilize significant amounts of inorganic salts. ${ }^{4-7}$ Functionalized ionic liquids are one means to circumvent the problem of low solubility: these ionic liquids have a built-in coordinating unit, such as a nitrile group which can bind to the metal ion, thereby increasing its solubility. ${ }^{8,9}$ An alternative approach to improve the solubility of metal ions in ionic liquids is to design ionic liquids with a

$\dagger$ Electronic Supplementary Information (ESI) available: SEM micrographs, EDX analysis and AFM images of deposited silver films. See DOI: 10.1039/b000000x/

${ }^{a}$ KU Leuven - University of Leuven, Department of Metallurgy and Materials Engineering, Kasteelpark Arenberg 44 - bus 2450, B-3001 Heverlee (Belgium)

${ }^{b}$ KU Leuven - University of Leuven, Department of Chemistry, Celestijnenlaan $200 F$ - bus 2404, B-3001 Heverlee (Belgium)

* jan.fransaer@mtm.kuleuven.be metal complex as part of their composition. ${ }^{10-15}$ Most ionic liquids of this type contain anionic metal complexes. Examples of such anionic complexes are $\left[\mathrm{AlCl}_{4}\right]^{-},\left[\mathrm{CoCl}_{4}\right]^{2-}$, $\left[\mathrm{ZnCl}_{4}\right]^{2-},\left[\mathrm{MnCl}_{4}\right]^{2-}$ and $\left[\mathrm{NiBr}_{3}(\mathrm{~L})\right]{ }^{16-20}$ Descriptions of anionic complexes such as $\left[\mathrm{WO}_{4}\right]^{2-}$ and $\left[\mathrm{Co}(\mathrm{CO})_{4}\right]^{-}$without halogen ligands are given by Brown et al. ${ }^{21}$ and Qiao et al. ${ }^{22}$ The advantages of complexing a metal ion with organic ligands, forming so-called Liquid Metal Salts (LMS), and the use of the formed complexes as the cation in an ionic liquid has already been reported for copper and silver. ${ }^{23-27}$ In those papers we showed some of our LMS are able to sustain high current densities. Other examples of cationic silver complexes, based on amine ligands, have been reported by Huang et al. ${ }^{28}$ but it is not stated what the highest achievable current density is, and Iida et al., ${ }^{29,30}$ who do not mention any electrochemical properties. Metallocenium ionic liquids have also been synthesized, but also for these compounds no electrochemical data were reported. ${ }^{31-34}$ So far, the positive charge of the metal complexes has very often been countered by use of $\left[\mathrm{Tf}_{2} \mathrm{~N}\right]^{-}$as the anion, as this typically gives lower melting points. Fluorinated anions were introduced in ionic liquids to replace the highly water-sensitive ions such as tetrachloroaluminate. Furthermore, they led to ionic liquids with low viscosities, and thus high electrical conductivities, because the negative charge is delocalized so that hydrogen bonding was weakened. The presence of fluorine might be problematic however, not only because of possible hydrolysis when traces of water are present (especially in $\left[\mathrm{BF}_{4}\right]^{-}$and $\left[\mathrm{PF}_{6}\right]^{-}$) but also due to restricted disposal options, sustainability and

S. Schaltin, N.R. Brooks, J. Sniekers, D. Depuydt. L. Van Meervelt,

K. Binnemans, J. Fransaer

Physical Chemistry Chemical Physics 15, 18934-18943 (2013) 
due to the elevated price of the more hydrolysis stable fluorinated anions such as $\left[\mathrm{Tf}_{2} \mathrm{~N}\right]^{-}$and trifluoromethanesulfonate $\left([\mathrm{TfO}]^{-}\right)$. There is a preference to avoid the use of fluorinecontaining ionic liquids for the reasons of price, the green credentials and sustainability. ${ }^{35}$ In this regard we have turned our attentions to developing fluorine-free LMS without having to compromise on applications. The complexes reported herein are are of the form $[\mathrm{AgAlkIm}]\left[\mathrm{NO}_{3}\right]$ AlkIm stands for $N$-alkylimidazole and is specifically either methyl-, ethyl-, butyl-, hexyl-, octyl-, decyl- or dodecylimidazole (later abbreviated as MeIm, EtIm, BuIm, HeIm, OcIm, DeIm and DoIm, respectively). We also report the synthesis of the heterolep-

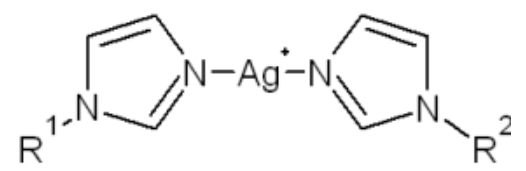

Fig. 1 Structural formula of the cations of this study, where $\mathrm{R}^{1}$ and $\mathrm{R}^{2}$ are methyl, ethyl, butyl, hexyl, octyl, decyl or dodecyl chains.

tic complex $[\mathrm{Ag}(\mathrm{MeIm})(\mathrm{EtIm})]\left[\mathrm{NO}_{3}\right]$. The complexes have been thoroughly characterised and, where possible, their solid state structures and their thermal and electrochemical chemical properties are reported. Iida et al. ${ }^{29}$ have also prepared silver-containing ionic liquids with nitrate as anion, but also for these compounds no electrochemical experiments were reported.

\section{Experimental}

\subsection{Synthesis}

Nitric acid was purchased from Chem Lab (NL) as a $65 \%$ watery solution. Silver(I) oxide was obtained from Alfa Aesar (USA) in $99+\%$ purity. All imidazoles were obtained from IoLiTec and were of reagent grade and used without further purification.

$\left[\mathrm{Ag}(\mathrm{MeIm})_{2}\right]\left[\mathrm{NO}_{3}\right]:$ To nitric acid $(0.713 \mathrm{~g}, 7.66 \mathrm{mmol}$; $65 \%$ in $\left.\mathrm{H}_{2} \mathrm{O}\right)$ in dichloromethane $(20 \mathrm{~mL})$ was added silver(I) oxide $(0.852 \mathrm{~g}, 3.678 \mathrm{mmol})$ and 1-methylimidazole $(1.208 \mathrm{~g}, 14.71 \mathrm{mmol})$ to give $\left[\mathrm{Ag}(\mathrm{MeIm})_{2}\right]\left[\mathrm{NO}_{3}\right](1.739 \mathrm{~g}$, $5.205 \mathrm{mmol}, 70.76 \%)$ as a slightly brown solid. Melting point: $86{ }^{\circ} \mathrm{C}$. $\mathrm{CHN}$ found (calculated for $\mathrm{C}_{8} \mathrm{H} 12 \mathrm{AgN}_{5} \mathrm{O}_{3}$ ): C 28.56 (28.76)\%, H 2.80 (3.60)\%; N 20.10 (20.96)\% IR $v / \mathrm{cm}^{-1}: 3138,3117,3049,2942,2372,1745,1630,1533$, 1521, 1471, 1419, 1318, 1284, 1237, 1097, 1040, 1025, 947, 845, 821, 766, 672, 650, 616, 521, 477, 438, $406 \mathrm{NMR}: \delta_{\mathrm{H}}$ $\left(300 \mathrm{MHz}, \mathrm{CDCl}_{3}\right): 8.01(\mathrm{~s}, 1 \mathrm{H}), 7.07(\mathrm{~s}, 1 \mathrm{H}), 6.99(\mathrm{~s}, 1 \mathrm{H})$, $3.74(\mathrm{~s}, 3 \mathrm{H}) ; \delta_{\mathrm{C}}\left(75 \mathrm{MHz}, \mathrm{CDCl}_{3}\right): 140.35,129.79,120.70$, 34.24. Crystal Data for $\mathrm{C}_{8} \mathrm{H}_{12} \mathrm{AgN}_{5} \mathrm{O}_{3}(\mathrm{M}=334.10)$ : colorless block $0.4 \times 0.2 \times 0.1 \mathrm{~mm}^{3}$, triclinic, space group $P-1$ (no.
2), $a=6.2877(2) \AA, b=7.7823(4) \AA, c=12.5635(5) \AA, \alpha$ $=88.036(4)^{\circ}, \beta=89.839(3)^{\circ}, \gamma=76.687(4)^{\circ}, V=597.89(4)$ $\AA^{3}, Z=2, T=293(2) \mathrm{K}, \mu($ Mo K $\alpha)=1.691 \mathrm{~mm}^{-1}$, Dcalc $=$ $1.856 \mathrm{~g} / \mathrm{cm}^{3}, 8680$ reflections measured $(6.18<2 \Theta<58.4)$, 2842 unique $\left(R_{\text {int }}=0.0185\right)$ which were used in all calculations. The final $R_{1}$ was $0.0247(>2 \operatorname{sigma}(\mathrm{I}))$ and $w R_{2}$ was 0.0662 (all data). Largest diff. peak/hole $0.45 /-0.35$ e $\AA^{-3}$.

$\left[\mathrm{Ag}(\mathrm{EtIm})_{2}\right]\left[\mathrm{NO}_{3}\right]$ : To nitric acid $(0.743 \mathrm{~g}, 7.66 \mathrm{mmol}$; $65 \%$ in $\left.\mathrm{H}_{2} \mathrm{O}\right)$ in acetonitrile $(20 \mathrm{~mL})$ was added silver(I) oxide $(0.888 \mathrm{~g}, 3.83 \mathrm{mmol})$ and 1-ethylimidazole $(1.47 \mathrm{~g}, 15.32$ $\mathrm{mmol}$ ). The mixture was stirred at room temperature for 1 hour. Remaining $\mathrm{Ag}_{2} \mathrm{O}$ was filtered off. The acetonitrile was removed on a rotary evaporator to give $\left[\mathrm{Ag}(\mathrm{EtIm})_{2}\right]\left[\mathrm{NO}_{3}\right]$ $(2.465 \mathrm{~g}, 6.18 \mathrm{mmol}, 88.86 \%$ ) as a slightly brown liquid. $\mathrm{CHN}$ found (calculated for $\mathrm{C}_{10} \mathrm{H}_{16} \mathrm{AgN}_{5} \mathrm{O}_{3}$ ): C 33.02 (33.17)\%, H 3.84 (4.45)\%; N 18.73 (19.34)\% IR $v / \mathrm{cm}^{-1}$ : $3116,2979,2365,1742,1671,1518,1465,1446,1322,1234$, 1113, 1093, 1034, 960, 946, 827, 748, 653, 626, 427, 416 NMR: $\delta_{\mathrm{H}}\left(300 \mathrm{MHz}, \mathrm{CDCl}_{3}\right): 8.06(\mathrm{~s}, 1 \mathrm{H}), 7.07(\mathrm{~d}, 2 \mathrm{H}), 4.05$ $(\mathrm{q}, 2 \mathrm{H}) 1.45(\mathrm{t}, 3 \mathrm{H}) ; \delta_{\mathrm{C}}\left(75 \mathrm{MHz}, \mathrm{CDCl}_{3}\right): 139.11,129.72$, 42.99, 15.98 .

$[\mathrm{Ag}(\mathrm{MeIm})(\mathrm{EtIm})]\left[\mathrm{NO}_{3}\right]: \quad$ To nitric acid $(0.799 \mathrm{~g}, 8.24$ mmol; $65 \%$ in $\left.\mathrm{H}_{2} \mathrm{O}\right)$ in dichloromethane $(20 \mathrm{~mL})$ was added silver(I) oxide (0.955 g, $4.12 \mathrm{mmol})$, 1-ethylimidazole (0.792 $\mathrm{g}, 8.24 \mathrm{mmol})$ and 1-methylimidazole $(0.677,8.24 \mathrm{mmol})$ to give $[\mathrm{Ag}(\mathrm{MeIm})(\mathrm{EtIm})]\left[\mathrm{NO}_{3}\right](2.481 \mathrm{~g}, 7.127 \mathrm{mmol}, 85.29 \%)$ as a slightly brown liquid. $\mathrm{CHN}$ found (calculated for $\left.\mathrm{C}_{9} \mathrm{H}_{14} \mathrm{AgN}_{5} \mathrm{O}_{3}\right)$ : C 31.12 (31.05)\%, H 3.31 (4.05)\%; N 19.46 (20.12)\% IR $v / \mathrm{cm}^{-1}$ : 3118, 2980, 1742, 1667, 1519, 1447, 1323, 1286, 1236, 1113, 1093, 1035, 947, 827, 749, 654, 620, 522, 481, $409 \mathrm{NMR}: \delta_{\mathrm{H}}\left(300 \mathrm{MHz}, \mathrm{CDCl}_{3}\right): 8.04(\mathrm{~s}, 1 \mathrm{H}), 7.98$ $(\mathrm{s}, 1 \mathrm{H}), 7.06(\mathrm{~m}, 4 \mathrm{H}), 4.06(\mathrm{q}, 2 \mathrm{H}), 3.73(\mathrm{~s}, 3 \mathrm{H}), 1.45(\mathrm{t}, 3 \mathrm{H}) ; \delta_{\mathrm{C}}$ $\left(75 \mathrm{MHz}, \mathrm{CDCl}_{3}\right): 140.10,139.00,129.65,120.92,119.21$, 42.76, 34.20, 15.96.

$\left[\mathrm{Ag}(\mathrm{BuIm})_{2}\right]\left[\mathrm{NO}_{3}\right]:$ To nitric acid $(0.850 \mathrm{~g}, 8.77 \mathrm{mmol}$; $65 \%$ in $\left.\mathrm{H}_{2} \mathrm{O}\right)$ in dichloromethane $(20 \mathrm{~mL})$ was added silver(I) oxide (1.00 g, $4.38 \mathrm{mmol})$ and 1-butylimidazole $(2.174 \mathrm{~g}$, $17.50 \mathrm{mmol})$ to give $\left[\mathrm{Ag}(\mathrm{BuIm})_{2}\right]\left[\mathrm{NO}_{3}\right](3.371 \mathrm{~g}, 8.06 \mathrm{mmol}$, $92 \%$ ) as a slightly brown liquid. CHN found (calculated for $\mathrm{C}_{14} \mathrm{H}_{24} \mathrm{~N}_{5} \mathrm{AgO}_{3}$ ): C 40.72 (40.20)\%, H 5.48 (5.78)\%, N 16.37 (16.74)\%. IR $v / \mathrm{cm}^{-1}: 3114,2957,2932,2872,1518,1460$, 1329, 1235, 1113, 1093, 1030, 948, 827, 749, 657, 629, 530. NMR: $\delta_{\mathrm{H}}\left(300 \mathrm{MHz}, \mathrm{CDCl}_{3}\right): 7.94(\mathrm{~s}, 1 \mathrm{H}), 7.00(\mathrm{t}, 1 \mathrm{H}), 6.94$ $(\mathrm{t}, 1 \mathrm{H}), 3.91(\mathrm{t}, 2 \mathrm{H}), 1.70$ (quin, $2 \mathrm{H}), 1.23(\mathrm{~m}, 2 \mathrm{H}), 0.86(\mathrm{t}$, $3 \mathrm{H}) ; \delta_{\mathrm{C}}\left(75 \mathrm{MHz}, \mathrm{CDCl}_{3}\right): 139.44,129.63,119.37,77.21$, 47.60, 32.71, 19.63, 13.48. Crystal Data for $\mathrm{C}_{14} \mathrm{H}_{24} \mathrm{AgN}_{5} \mathrm{O}_{3}$ $(\mathrm{M}=418.25)$ : colorless block $0.4 \times 0.3 \times 0.1 \mathrm{~mm}^{3}$, monoclinic, space group $P 2_{1} / c$ (no. 14), $a=16.4340$ (13) $\AA, b=7.8736(7)$ $\AA, c=13.8845(13) \AA, \beta=106.748(9)^{\circ}, V=1720.4(3) \AA^{3}, Z$ $=4, T=100(2) \mathrm{K}, \mu($ Mo K $\alpha)=1.193 \mathrm{~mm}^{-1}$, Dcalc $=1.615$ $\mathrm{g} / \mathrm{cm}^{3}, 7334$ reflections measured $(5.78<2 \Theta<58.48), 3931$ unique $\left(\mathrm{R}_{\text {int }}=0.0172\right)$ which were used in all calculations. 
The final $R_{1}$ was 0.0218 (>2sigma(I)) and $w R_{2}$ was 0.0511 (all data). Largest diff. peak/hole: $0.54 /-0.51$ e $\AA-3$.

$\left[\mathrm{Ag}(\mathrm{HeIm})_{2}\right]\left[\mathrm{NO}_{3}\right]:$ To nitric acid $(0.850 \mathrm{~g}, 8.77 \mathrm{mmol}$; $65 \%$ in $\left.\mathrm{H}_{2} \mathrm{O}\right)$ in dichloromethane $(20 \mathrm{~mL})$ was added silver(I) oxide (1.00 g, $4.38 \mathrm{mmol})$ and 1-hexylimidazole $(2.664 \mathrm{~g}$, $17.50 \mathrm{mmol})$ to give $\left[\mathrm{Ag}(\mathrm{HeIm})_{2}\right]\left[\mathrm{NO}_{3}\right](3.924 \mathrm{~g}, 8.27 \mathrm{mmol}$, 94\%) as a slightly brown liquid. $\mathrm{CHN}$ found (calculated for $\mathrm{C}_{18} \mathrm{H}_{32} \mathrm{~N}_{5} \mathrm{AgO}_{3}$ ): C 45.62 (45.58)\%, H 7.57 (6.80)\%, N 14.38 (14.76)\%. IR $v / \mathrm{cm}^{-1}: 3113,2953,2928,2858,1518,1456$, 1329, 1237, 1112, 1092, 1036, 947, 828, 736, 657, 629, 465, 449, 438, 414. NMR: $\delta_{\mathrm{H}}\left(300 \mathrm{MHz}, \mathrm{CDCl}_{3}\right): 7.96(\mathrm{~s}, 1 \mathrm{H})$, $7.03(\mathrm{t}, 1 \mathrm{H}), 6.95(\mathrm{t}, 1 \mathrm{H}), 3.93(\mathrm{t}, 2 \mathrm{H}), 1.74$ (quin, $2 \mathrm{H}), 1.24$ $(\mathrm{m}, 6 \mathrm{H}), 0.84(\mathrm{t}, 3 \mathrm{H}) ; \delta_{\mathrm{C}}\left(75 \mathrm{MHz}, \mathrm{CDCl}_{3}\right): 139.38,129.64$, 119.25, 77.13, 47.86, 31.17, 30.76, 26.12, 22.42, 13.95 .

$\left[\mathrm{Ag}(\mathrm{OcIm})_{2}\right]\left[\mathrm{NO}_{3}\right]:$ To nitric acid $(0.850 \mathrm{~g}, 8.77 \mathrm{mmol}$; $65 \%$ in $\left.\mathrm{H}_{2} \mathrm{O}\right)$ in dichloromethane $(20 \mathrm{~mL})$ was added silver(I) oxide (1.00 g, $4.38 \mathrm{mmol})$ and 1-octylimidazole $(3.155 \mathrm{~g}$, $17.50 \mathrm{mmol})$ to give $\left[\mathrm{Ag}(\mathrm{OcIm})_{2}\right]\left[\mathrm{NO}_{3}\right](4.302 \mathrm{~g}, 8.11 \mathrm{mmol}$, $92 \%$ ) as a slightly brown liquid. $\mathrm{CHN}$ found (calculated for $\mathrm{C}_{22} \mathrm{H}_{40} \mathrm{~N}_{5} \mathrm{AgO}_{3}$ ): C $49.96(49.81) \%, \mathrm{H} 8.40$ (7.60)\%, N 13.11 (13.20)\%. IR $v / \mathrm{cm}^{-1}: 3113,2924,2855,1518,1464,1330$, 1237, 1172, 1113, 1092, 1037, 947, 827, 736, 657, 628, 548, 516, 489, 470, 433. NMR: $\delta_{\mathrm{H}}\left(300 \mathrm{MHz}, \mathrm{CDCl}_{3}\right): 8.02$ $(\mathrm{s}, 1 \mathrm{H}), 7.01(\mathrm{~s}, 2 \mathrm{H}), 3.96(\mathrm{~s}, 2 \mathrm{H}), 1.76(\mathrm{~s}, 2 \mathrm{H}), 1.24(\mathrm{~m}$, $10 \mathrm{H}), 0.85(\mathrm{t}, 3 \mathrm{H}) ; \delta_{\mathrm{C}}\left(75 \mathrm{MHz}, \mathrm{CDCl}_{3}\right): 77.52,77.10,76.68$, 31.70, 29.03, 22.59, 14.07 .

$\left[\mathrm{Ag}(\mathrm{DeIm})_{2}\right]\left[\mathrm{NO}_{3}\right]:$ To nitric acid $(0.850 \mathrm{~g}, 8.77 \mathrm{mmol}$; $65 \%$ in $\left.\mathrm{H}_{2} \mathrm{O}\right)$ in dichloromethane $(20 \mathrm{~mL})$ was added silver(I) oxide (1.00 g, $4.38 \mathrm{mmol})$ and 1-decylimidazole (3.646 g, $17.50 \mathrm{mmol})$ to give $\left[\mathrm{Ag}(\mathrm{DeIm})_{2}\right]\left[\mathrm{NO}_{3}\right](4.726 \mathrm{~g}, 8.05 \mathrm{mmol}$, $92 \%$ ) as a slightly brown solid. Melting point: $41{ }^{\circ} \mathrm{C}$. CHN found (calculated for $\mathrm{C}_{26} \mathrm{H}_{48} \mathrm{~N}_{5} \mathrm{AgO}_{3}$ ): $\mathrm{C} 53.33$ (53.24)\%, $\mathrm{H}$ 8.99 (8.25)\%, N 12.03 (11.94)\%. IR $v / \mathrm{cm}^{-1}$ : 3117, 2918, 2851, 1739, 1669, 1516, 1468, 1446, 1328, 1278, 1252, 1233, 1114, 1097, 1027, 946, 823, 780, 741, 720, 658, 632, 470, 446. NMR: $\delta_{\mathrm{H}}\left(300 \mathrm{MHz}, \mathrm{CDCl}_{3}\right): 8.00(\mathrm{~s}, 1 \mathrm{H}), 7.05(\mathrm{t}, 1 \mathrm{H})$, $6.96(\mathrm{t}, 1 \mathrm{H}), 3.95(\mathrm{t}, 2 \mathrm{H}), 1.77$ (quin, 2H), $1.26(\mathrm{~m}, 14 \mathrm{H}), 0.86$ $(\mathrm{t}, 3 \mathrm{H}) ; \delta_{\mathrm{C}}\left(75 \mathrm{MHz}, \mathrm{CDCl}_{3}\right): 139.55,129.64,119.16,77.06$, $47.92,31.85,30.79,29.46,29.39,29.25,29.03,26.49,22.67$, 14.11 .

$\left[\mathrm{Ag}(\mathrm{DoIm})_{2}\right]\left[\mathrm{NO}_{3}\right]:$ To nitric acid $(0.850 \mathrm{~g}, 8.77 \mathrm{mmol}$; $65 \%$ in $\left.\mathrm{H}_{2} \mathrm{O}\right)$ in dichloromethane $(20 \mathrm{~mL})$ was added silver(I) oxide $(1.00 \mathrm{~g}, 4.38 \mathrm{mmol})$ and 1-dodecylimidazole $(4.137 \mathrm{~g}$, $17.50 \mathrm{mmol})$ to give $\left[\mathrm{Ag}(\mathrm{DoIm})_{2}\right]\left[\mathrm{NO}_{3}\right](5.039 \mathrm{~g}, 7.84 \mathrm{mmol}$, $89 \%$ ) as a slightly brown solid. Melting point: $56{ }^{\circ} \mathrm{C}$. IR $v / \mathrm{cm}^{-1}$ : 3116, 2917, 2850, 1671, 1566, 1515, 1467, 1445, 1330, 1279, 1231, 1113, 1096, 1029, 945, 907, 824, 778, 720, 659, 631, 518, 491, 469. NMR: $\delta_{\mathrm{H}}\left(300 \mathrm{MHz}, \mathrm{CDCl}_{3}\right): 7.81$ $(\mathrm{s}, 1 \mathrm{H}), 7.05(\mathrm{t}, 1 \mathrm{H}), 3.93(\mathrm{t}, 1 \mathrm{H}), 3.93(\mathrm{t}, 2 \mathrm{H}), 1.77$ (quin, 2H), $1.25(\mathrm{~m}, 18 \mathrm{H}), 0.86(\mathrm{t}, 3 \mathrm{H}) ; \delta_{\mathrm{C}}\left(75 \mathrm{MHz}, \mathrm{CDCl}_{3}\right): 138.70$, $129.54,119.02,77.06,47.61,31.91,30.90,29.60,29.51$, $29.41,29.33,29.05,26.51,22.69,14.12$. Crystal Data for
$\mathrm{C}_{30} \mathrm{H}_{60} \mathrm{AgN}_{5} \mathrm{O}_{5}(\mathrm{M}=678.70)$ : colorless plate $0.1 \times 0.1 \times 0.02$ $\mathrm{mm}^{3}$, triclinic, space group $P-1$ (no. 2 ), $a=4.5579$ (4) $\AA, b=$ 8.2220(5) $\mathrm{A}, c=23.099(2) \AA, \alpha=89.274(7)^{\circ}, \beta=87.415(7)^{\circ}$, $\gamma=78.188(6)^{\circ}, V=846.45(12) \AA^{3}, Z=1, T=100(2) \mathrm{K}$, $\mu($ Mo K $\alpha)=0.638 \mathrm{~mm}^{-1}$, Dcalc $=1.331 \mathrm{~g} / \mathrm{cm}^{3}, 6872 \mathrm{re}-$ flections measured $(6.16<2 \Theta<58.42), 3850$ unique $\left(\mathrm{R}_{\text {int }}=\right.$ $0.0434)$ which were used in all calculations. The final $R_{1}$ was 0.0526 ( $>2$ sigma(I)) and $w R_{2}$ was 0.0937 (all data). Largest diff. peak/hole $0.51 /-0.92$ e $\AA^{-3}$.

\subsection{Characterization}

TGA studies were preformed on a TA instruments Q600 thermogravimeter. The temperature was scanned from room temperature up to $400{ }^{\circ} \mathrm{C}$ at $5{ }^{\circ} \mathrm{C} \mathrm{min}^{-1}$. Melting points were determined with a Mettler-Toledo 822 DSC instrument using a heating rate of $10{ }^{\circ} \mathrm{C} \mathrm{min}-1$ in a helium atmosphere. Viscosities have been measured with a Brookfield cone plate viscosimeter (LVDV-II+ Programmable Viscometer) with a cone spindle CPE-40. The ionic liquid was kept under dry nitrogen atmosphere during the measurement and the temperature of the sample was controlled by a circulating water bath. FTIR spectra were recorded with a Bruker Vertex 70 FTIR spectrometer, equipped with a Platinum ATR accessory. $1 \mathrm{H}$ and 13C NMR measurements were done with a Bruker Avance $300 \mathrm{MHz}$ spectrometer. Elemental analyses (C, H, N) were performed by using a CE Instruments EA-1110 elemental analyser.

Crystals of $\left[\mathrm{Ag}(\mathrm{MeIm})_{2}\right]\left[\mathrm{NO}_{3}\right]$ suitable for single crystal $\mathrm{X}$-ray diffraction were mounted on a nylon loop attached to a copper pin and placed on an Agilent SuperNova diffractometer at room temperature $(293(2) \mathrm{K})$ using $\mathrm{Mo}_{\alpha}$ radiation $(\lambda=0.71073 \AA)$, whilst those of $\left[\mathrm{Ag}(\mathrm{BuIm})_{2}\right]\left[\mathrm{NO}_{3}\right]$ and $\left[\mathrm{Ag}(\mathrm{DoIm})_{2}\right]\left[\mathrm{NO}_{3}\right] \cdot 2 \mathrm{H}_{2} \mathrm{O}$ were placed into the cold stream of an Oxford Cryostream 700 at $100(2) \mathrm{K}$ on the same diffractometer. The absorption corrections were applied using CrysAlisPro. ${ }^{36}$ All structures were solved using direct methods and refined by the full-matrix least-squares procedure in SHELXL. ${ }^{37}$ All hydrogen atoms were placed in calculated positions and refined using a riding model. A summary of the crystallographic data can be found in the experimental section and pertinent bond lengths are mentioned in the text. The program OLEX2 was also used in refinement and making pictures. ${ }^{38}$ The structure of $\left[\mathrm{Ag}(\mathrm{DoIm})_{2}\right]\left[\mathrm{NO}_{3}\right] \cdot 2 \mathrm{H}_{2} \mathrm{O}$ contained disorder with the $\left[\mathrm{NO}_{3}\right]^{-}$anions and hydrate water molecules occupying the same space in the structure with occupancies of $50 \%$ each. The hydrogen atoms of the disordered waters could not be located in the difference density electron map but are included in the general formula. 


\subsection{Electrochemistry}

Gold-covered silicon wafers were used as substrates for electrodeposition ( $\mathrm{Si}, 500 \mathrm{~nm} \mathrm{SiO}, 10 \mathrm{~nm} \mathrm{Ti}, 100 \mathrm{~nm} \mathrm{Au}$ ). In order to make the current density uniform across the whole electrode area, the electrode was recessed by placing it inside a PTFE-sample holder, which decreased the tendency for dendritic growth because the electric field in the recess is homogenous. The presence of dendrites increases the actual surface area which means that the real current density is lower than the value based on the geometrical surface area of the electrode. A complete description of the electrochemical cell is given elsewhere. ${ }^{23}$ Before use, the substrates were cleaned by rinsing with acetone and dried. After the deposition of a silver layer, the deposit was rinsed with acetone and dried. The electrolyte was contained in a platinum crucible, and it was not stirred during the experiments. The temperature was held at $90{ }^{\circ} \mathrm{C}$ for all electrochemical experiments, unless mentioned otherwise. This temperature was chosen because it is high enough that all tested compounds are liquid at this temperature but not so high that the compounds decompose. A higher temperature also reduces viscosity and enhances the mass transport properties. These experiments were done using a Solartron instruments SI 1287 Electrochemical interface controlled by a computer with Corrware software. All potential values in this paper are relative to a silver wire directly immersed in solution (pseudo-reference electrode). If required, the potential values were corrected for the $i R$ drop in real time by using the current interrupt technique. A silver coil was used as counter electrode. It is known that ionic liquids, even the most hydrophobic ones, can take up atmospheric moisture which might alter the deposit morphology, depending on the amount of absorbed water. ${ }^{39}$ Therefore, all electrochemical experiments were performed in an argon-filled glove box (with $\mathrm{O}_{2}$ and $\mathrm{H}_{2} \mathrm{O}$ concentrations below $1 \mathrm{ppm})$. Experiments with the Quartz Crystal Microbalance (QCM) were executed with a Maxtex RQCM. The morphology and elemental composition of the silver deposits were determined by scanning electron microscopy (SEM) and energydispersive X-ray analysis (EDX) (Philips XL 30 FEG), and atomic force microscopy (AFM) (Bruker Dimension 3000).

\section{Results and discussion}

Ionic liquids of the general formula $\left[\mathrm{AgAlkIm} /\left[\mathrm{NO}_{3}\right]\right.$ have been synthesized by one of two methods, depending on the silver starting material used. Firstly, by the action of nitric acid on $\mathrm{Ag}_{2} \mathrm{O}$ in the presence of two equivalents of $\mathrm{N}$ alkylimidazole ligand and secondly by direct addition of the ligand to a solution of $\mathrm{AgNO}_{3}$. Acetonitrile was typically used as the solvent in both of these methods, but other solvents were also successfully tried. Whilst the second method is simpler, the first method was used more for synthesis of larger amounts of material.

The melting points of the silver(I) complexes depended on the alkyl chain length of the imidazole (Table 1). The com-

Table 1 Melting points $\left({ }^{\circ} \mathrm{C}\right.$ ) of compounds $\left[\mathrm{AgL}_{1} \mathrm{~L}_{2}\right]\left[\mathrm{NO}_{3}\right]$ (this work) and $\left[\mathrm{AgL}_{1} \mathrm{~L}_{2}\right]\left[\mathrm{Tf}_{2} \mathrm{~N}\right] .{ }^{26}$

\begin{tabular}{ccc}
\hline & {$\left[\mathrm{NO}_{3}\right]^{-}$} & {$\left[\mathrm{Tf}_{2} \mathrm{~N}\right]^{-}$} \\
\hline$\left[\mathrm{Ag}(\mathrm{MeIm})_{2}\right]^{+}$ & 86 & 87 \\
{$\left[\mathrm{Ag}(\mathrm{EtIm})_{2}\right]^{+}$} & $<\mathrm{RT}^{a}$ & 65 \\
{$\left[\mathrm{Ag}(\mathrm{BuIm})_{2}\right]^{+}$} & 58 & 42 \\
{$\left[\mathrm{Ag}(\mathrm{HeIm})_{2}\right]^{+}$} & $<\mathrm{RT}^{a}$ & \\
{$\left[\mathrm{Ag}(\mathrm{OcIm})_{2}\right]^{+}$} & $<\mathrm{RT}^{a}$ \\
{$\left[\mathrm{Ag}(\mathrm{DeIm})_{2}\right]^{+}$} & 41 \\
{$\left[\mathrm{Ag}(\mathrm{DoIm})_{2}\right]^{+}$} & 56 \\
{$\left[\mathrm{Ag}(\mathrm{MeIm})(\mathrm{EtIm})^{+}\right.$} & $<\mathrm{RT}^{a}$ \\
\hline${ }^{a}<\mathrm{RT}$ means that compounds were not found \\
to solidify after a long time in a freezer at \\
$-20{ }^{\circ} \mathrm{C}$ or several hours in a DSC apparatus at \\
$-60{ }^{\circ} \mathrm{C}$.
\end{tabular}

pound $\left[\mathrm{Ag}(\mathrm{MeIm})_{2}\right]\left[\mathrm{NO}_{3}\right]$ has the highest melting point in the series $\left(86{ }^{\circ} \mathrm{C}\right)$. The compound $\left[\mathrm{Ag}(\mathrm{EtIm})_{2}\right]\left[\mathrm{NO}_{3}\right]$ was a liquid at room temperature and, despite many efforts to increase purity and placing in a freezer for several weeks, could not be solidified. Also no evidence of a glass transition could be determined down to $-60^{\circ} \mathrm{C}$. It was also initially assumed that the compound $\left[\mathrm{Ag}(\mathrm{BuIm})_{2}\right]\left[\mathrm{NO}_{3}\right]$ was a liquid at room temperature as for the first five or six times the compound was synthesized it appeared to be a liquid, however, suddenly during one synthesis the compound spontaneously crystallized and was found to have a melting point of $58{ }^{\circ} \mathrm{C}$. It is not known why the product suddenly solidified as nothing different was done on this particular synthesis. The analysis of the products from each synthesis showed they were pure in each case, but perhaps a slight impurity prevents the sample from crystallizing, or perhaps in this case a crystallization nucleus was formed by mere chance. The compounds of $\left[\mathrm{Ag}(\mathrm{HeIm})_{2}\right]\left[\mathrm{NO}_{3}\right]$ and $\left[\mathrm{Ag}(\mathrm{OcIm})_{2}\right]\left[\mathrm{NO}_{3}\right]$ were also synthesized as liquids, whereas $\left[\mathrm{Ag}(\mathrm{DeIm})_{2}\right]\left[\mathrm{NO}_{3}\right]$ and $\left[\mathrm{Ag}(\mathrm{DoIm})_{2}\right]\left[\mathrm{NO}_{3}\right]$ were solids with melting points 41 and $56{ }^{\circ} \mathrm{C}$, respectively. The heteroleptic compound $[\mathrm{Ag}(\mathrm{MeIm})(\mathrm{EtIm})]\left[\mathrm{NO}_{3}\right]$ was also synthesized and found to be a liquid at room temperature. Comparing the melting points of the compounds $[\mathrm{AgAlkIm} 2]\left[\mathrm{NO}_{3}\right]$ with the analogues with a bis(trifluoromethylsulfonyl)imide anion, namely $[\mathrm{AgAlkIm} 2]\left[\mathrm{Tf}_{2} \mathrm{~N}\right],{ }^{26}$ it is rather surprising that the nitrate salts have such low melting points. In general, the bis(trifluoromethylsulfonyl)imide anion is often the anion of choice to obtain low-melting ionic liquids, but here the complexes $\left[\mathrm{Ag}(\mathrm{MeIm})_{2}\right]\left[\mathrm{NO}_{3}\right]$ and $\left[\mathrm{Ag}(\mathrm{MeIm})_{2}\right]\left[\mathrm{Tf}_{2} \mathrm{~N}\right]$ have very similar melting points, whilst 
for the EtIm analogues the nitrate compound is a liquid, whereas the bis(trifluoromethylsulfonyl)imide analogue melts at $65{ }^{\circ} \mathrm{C}$. In the case of BuIm, the melting point of the nitrate compound $\left(58{ }^{\circ} \mathrm{C}\right)$ is slightly higher than that of the bis(trifluoromethylsulfonyl)imide compound $\left(42{ }^{\circ} \mathrm{C}\right)$. For the heteroleptic MeIm/EtIm compounds, in the case of nitrate anion the compound is a liquid, whereas the bis(trifluoromethylsulfonyl)imide compound is a solid with a melting point of $35^{\circ} \mathrm{C} .{ }^{26}$

For some of the compounds that exist as solids it was possible to grow single crystals and analyse them with X-ray diffraction thus we present the structures of $\left[\mathrm{Ag}(\mathrm{MeIm})_{2}\right]\left[\mathrm{NO}_{3}\right]$, $\left[\mathrm{Ag}(\mathrm{BuIm})_{2}\right]\left[\mathrm{NO}_{3}\right]$ and $\left[\mathrm{Ag}(\mathrm{DoIm})_{2}\right]\left[\mathrm{NO}_{3}\right] \cdot 2 \mathrm{H}_{2} \mathrm{O}$. The structure of $\left[\mathrm{Ag}(\mathrm{MeIm})_{2}\right]\left[\mathrm{NO}_{3}\right]$ comprises one cation and one anion in the crystallographic asymmetric unit, with the silver(I) center coordinated by two MeIm ligands in a linear fashion (Fig. 2 : $\left.\mathrm{N}-\mathrm{Ag}-\mathrm{N}=174.17(7)^{\circ}\right)$. The two imidazolium rings coordinated to the silver(I) center are twisted by $29.10(2)^{\circ}$ with respect to each other. There are four further longer contacts between the silver(I) center and the oxygen atoms of $\mathrm{NO}_{3}$ at distances of $\mathrm{Ag} \cdots \mathrm{O}=2.911,3.027,3.128,3.173 \AA$, but these are much longer than the sum of the ionic radii of silver and oxygen $(2.55 \AA)$ so cannot be considered bonds but are shorter that the van der Waals radii of silver and oxygen (3.24 $\AA) .{ }^{40}$ These contacts mean that each $\mathrm{NO}_{3}$ anion is interacting with two silver(I) centers in a bidentate fashion creating chains that run parallel to the crystallographic $a$ axis (Fig. 2). There are additional weak $\mathrm{C}-\mathrm{H} \cdots \mathrm{O}$ hydrogen-bonds $(\mathrm{H} \cdots \mathrm{O}$ $=2.472,2.497 \AA$ ) that link adjacent chains to give the overall packing motif (Fig. 2). The structure of $\left[\mathrm{Ag}(\mathrm{BuIm})_{2}\right]\left[\mathrm{NO}_{3}\right]$ also comprises one cation and one anion in the crystallographic asymmetric unit, with the silver(I) center coordinated by two BuIm ligands, but, in contrast to the MeIm structure, the deviation from linear is much larger with $\mathrm{N}-\mathrm{Ag}-\mathrm{N}=$ $164.80(6)^{\circ}$ (Fig. 3). The two imidazolium rings coordinated to the silver(I) center are twisted by $18.57(8)^{\circ}$ with respect to each other. The $\mathrm{C}-\mathrm{N}-\mathrm{C}-\mathrm{C}$ torsion angle that defines the angle of the butyl chain with respect to the imidazolium ring is $131.64(18)^{\circ}$ and $49.4(3)^{\circ}$ for the two BuIm ligands. The butyl chains themselves have different conformations, one has almost linear torsion angles, whilst the other has a gauche conformation with a $\mathrm{C}-\mathrm{C}-\mathrm{C}-\mathrm{C}$ torsion angle of $67.6(2)^{\circ}$. There are three further longer contacts between the silver(I) center and the oxygen atoms of the nitrate groups at distances of $\mathrm{Ag} \cdots \mathrm{O}=2.711,3.000,3.120 \AA$. The shortest of these contacts is closer to the sum of the ionic radii of silver and oxygen ( $2.55 \AA$ ) than compared to the MeIm compound, but is still too long to be considered a bond. These contacts mean that each nitrate anion is interacting with two silver(I) centers, one in a bidentate fashion and one in a monodentate fashion creating chains that run parallel to the crystallographic $c$ axis (Fig. 4). Crystals of $\left[\mathrm{Ag}(\mathrm{DoIm})_{2}\right]\left[\mathrm{NO}_{3}\right] \cdot 2 \mathrm{H}_{2} \mathrm{O}$ were grown from

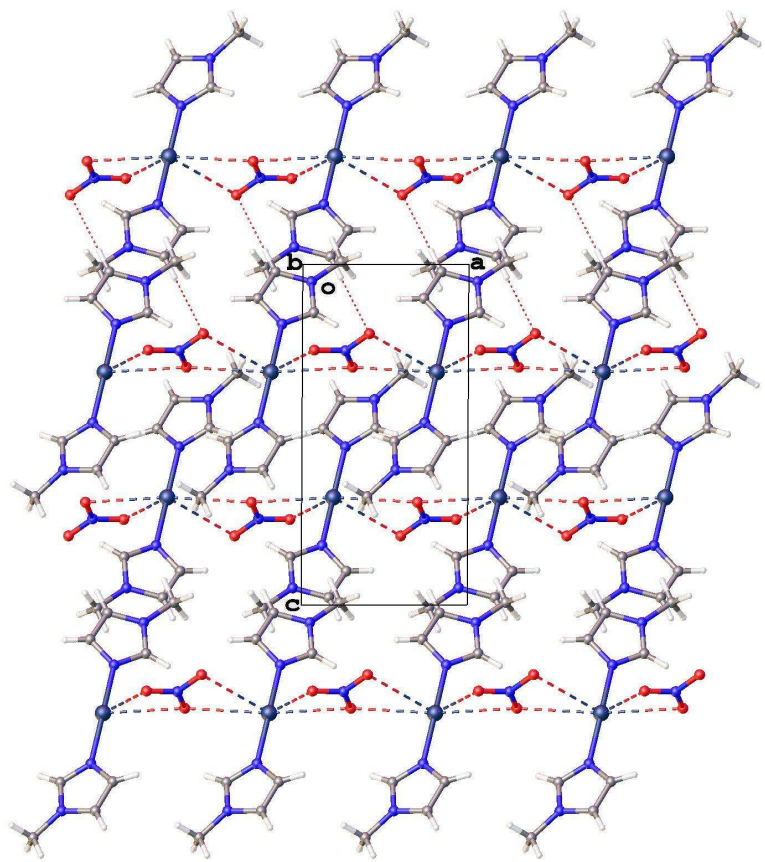

Fig. 2 View of the packing in the crystal structure of $\left[\mathrm{Ag}(\mathrm{MeIm})_{2}\right]\left[\mathrm{NO}_{3}\right]$ showing the linear coordination of the cation, the long $\mathrm{Ag} \cdots \mathrm{O}$ contacts that form polymeric chains, and the weak $\mathrm{C}-\mathrm{H} \cdots \mathrm{O}$ hydrogen bonds.

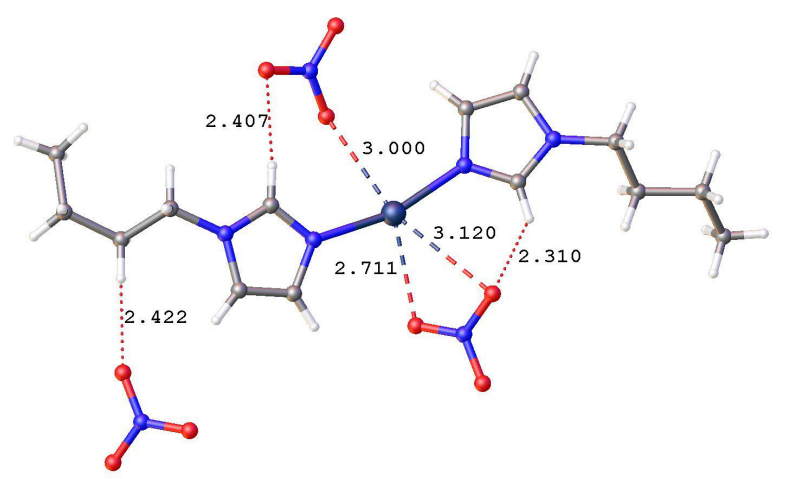

Fig. 3 View of the cation conformation and intermolecular interactions in the crystal structure of $\left[\mathrm{Ag}(\mathrm{BuIm})_{2}\right]\left[\mathrm{NO}_{3}\right]$. 


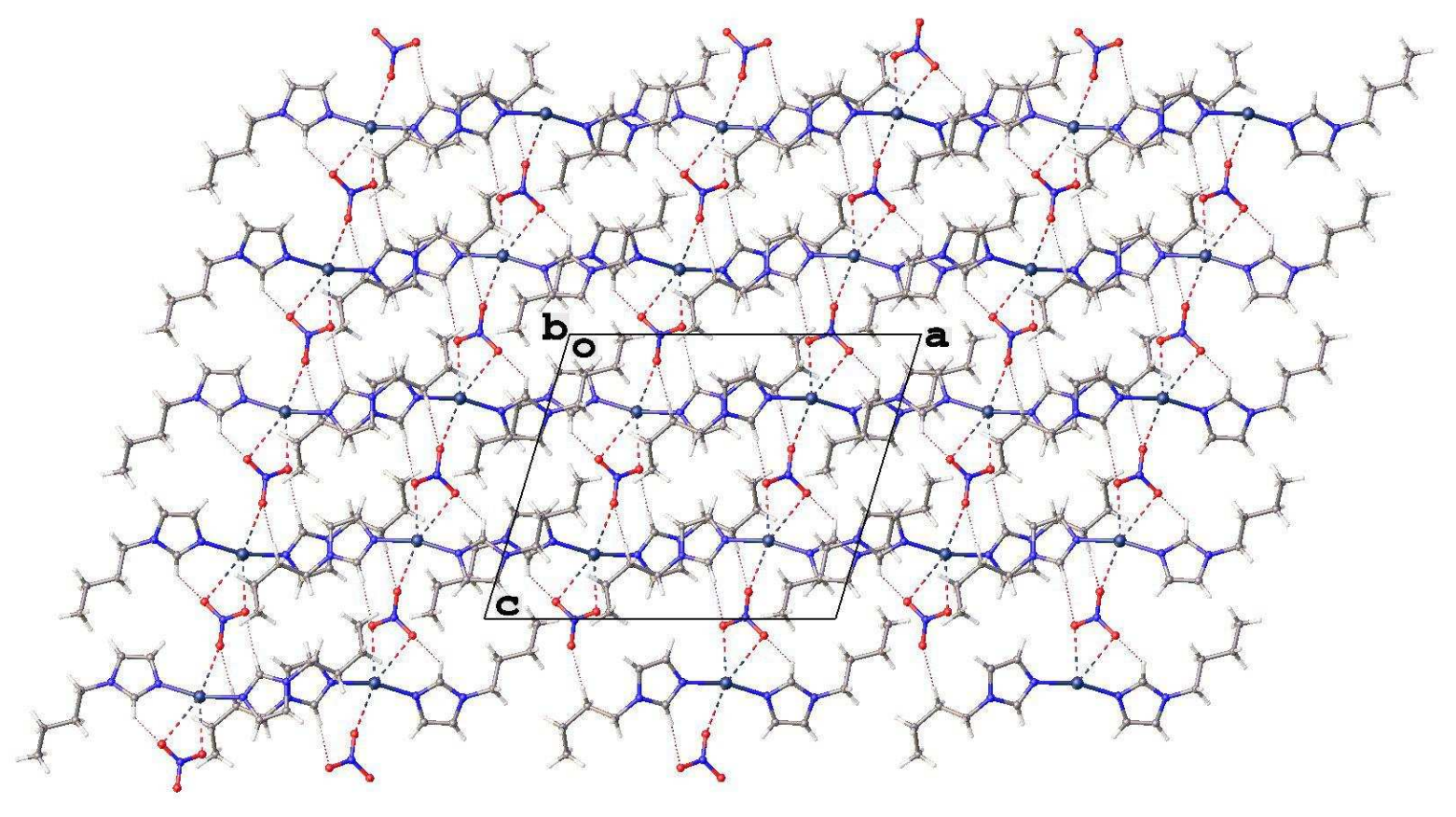

Fig. 4 View of the packing in the crystal structure of $\left[\mathrm{Ag}(\mathrm{BuIm})_{2}\right]\left[\mathrm{NO}_{3}\right]$ showing the long $\mathrm{Ag} \cdots \mathrm{O}$ contacts that form polymeric chains and the weak $\mathrm{C}-\mathrm{H} \cdots \mathrm{O}$ hydrogen bonds.

slow evaporation from acetonitrile, but atmospheric water has been included in the structure. A structure of the non-hydrated $\left[\mathrm{Ag}(\mathrm{DoIm})_{2}\right]\left[\mathrm{NO}_{3}\right]$ has already been published. ${ }^{41}$ The structure of $\left[\mathrm{Ag}(\mathrm{DoIm})_{2}\right]\left[\mathrm{NO}_{3}\right] \cdot 2 \mathrm{H}_{2} \mathrm{O}$ comprises the cation located on a crystallographic inversion center so there is half of one cation in the crystallographic asymmetric unit. The nitrate anion and the water molecules are disordered such that in each asymmetric unit, for half the time there is a nitrate anion and for the other half the time there are two water molecules. The silver(I) center is coordinated by two DoIm ligands in a linear geometry (Fig. 5: $\mathrm{N}-\mathrm{Ag}-\mathrm{N}=180^{\circ}$ by symmetry) The two imidazolium rings coordinated to the silver(I) center are coplanar due to the symmetry. The $\mathrm{C}-\mathrm{N}-\mathrm{C}-\mathrm{C}$ torsion angle that defines angle of the dodecyl chain with respect to the imidazolium ring is $-84.7(3)^{\circ}$, but the chain itself has almost linear torsion angles. These linear dodecyl chains are in contrast to the structure of $\left[\mathrm{Ag}(\mathrm{DoIm})_{2}\right]\left[\mathrm{NO}_{3}\right]$, which has a gauche conformation at the start of the dodecyl chains and consequently an overall U-shaped conformation. ${ }^{41}$ In $\left[\mathrm{Ag}(\mathrm{DoIm})_{2}\right]\left[\mathrm{NO}_{3}\right] \cdot 2 \mathrm{H}_{2} \mathrm{O}$ there are two further longer contacts between the silver(I) center and the oxygen atoms of the nitrate group and the water molecule, at distances of Ag...O $=3.072,3.180 \AA$, respectively. Although it was not possible to locate the hydrogen atoms on the disordered water molecules, it can be seen from the $\mathrm{O} \cdots \mathrm{O}$ distances that the disordered nitrate anions and water molecules create a hydrogen-bonded chain along the crystallographic $a$ axis $(\mathrm{O} \cdots \mathrm{O}=2.810-2.996$ Å).

For the liquids that were selected for electrochemical experiments (based on viscosity data: vide infra), a thermogravimetrical analysis (TGA) was done to measure their thermal stability. This is required because the main electrochemical experiments were conducted at $90{ }^{\circ} \mathrm{C}$. The results are presented in Fig. 6. The three tested ionic liquids $\left(\left[\mathrm{Ag}(\mathrm{EtIm})_{2}\right]\left[\mathrm{NO}_{3}\right], \quad[\mathrm{Ag}(\mathrm{MeIm})(\mathrm{EtIm})]\left[\mathrm{NO}_{3}\right]\right.$ and $\left.\left[\mathrm{Ag}(\mathrm{BuIm})_{2}\right]\left[\mathrm{NO}_{3}\right]\right)$ have a similar thermal stability: no mass loss is measured until the temperature exceeds $150{ }^{\circ} \mathrm{C}$, which means they can be used at $90{ }^{\circ} \mathrm{C}$ without thermal decomposition. Only at more elevated temperatures, the ligands are expelled. The thermal stabilities of these liquid metal salts based on nitrate anions are similar to analogue silverimidazole complexes with the bistriflimide anion $\left[\mathrm{Tf}_{2} \mathrm{~N}\right]^{-}{ }^{25}$ The main difference is the plateau in the remaining mass that is reached at $300{ }^{\circ} \mathrm{C}$. These plateau levels are $30.8 \%, 31.6 \%$ and $28.4 \%$ for $\left[\mathrm{Ag}(\mathrm{EtIm})_{2}\right]\left[\mathrm{NO}_{3}\right],[\mathrm{Ag}(\mathrm{MeIm})(\mathrm{EtIm})]\left[\mathrm{NO}_{3}\right]$ and $\left[\mathrm{Ag}(\mathrm{BuIm})_{2}\right]\left[\mathrm{NO}_{3}\right]$, respectively. The experimental values are close to the theoretical values $(32.0 \%, 33.3 \%$ and $29.7 \%)$ assuming that the liquid metal salts decompose to $\mathrm{Ag}_{2} \mathrm{O}$. The measured masses are about $1 \%$ smaller than the theoretical ones. This is probably caused by the fact that the ligand-tosilver ratio is slightly larger than two after synthesis of the liquid metal salt. From the values that are mentioned in the 


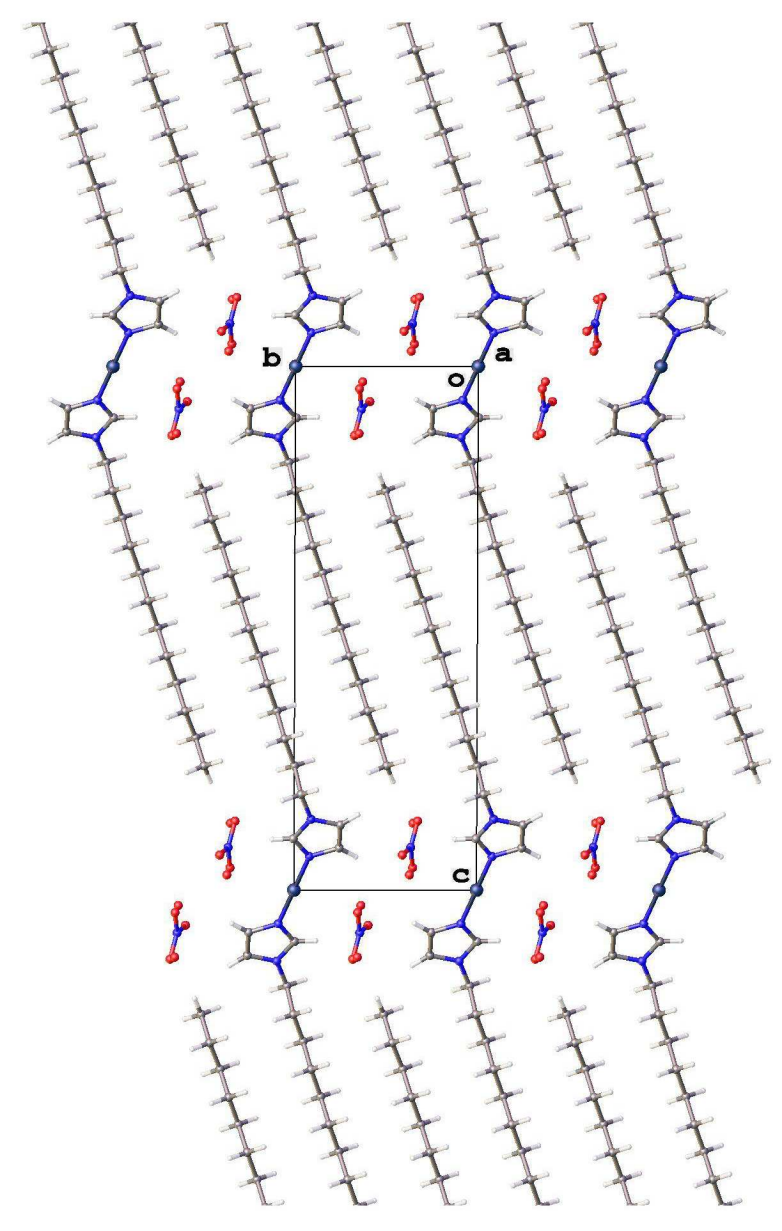

Fig. 5 View of the packing in the crystal structure of $\left[\mathrm{Ag}(\mathrm{DoIm})_{2}\right]\left[\mathrm{NO}_{3}\right] \cdot 2 \mathrm{H}_{2} \mathrm{O}$ showing the linear coordination of the cation and the linear dodecyl chains.

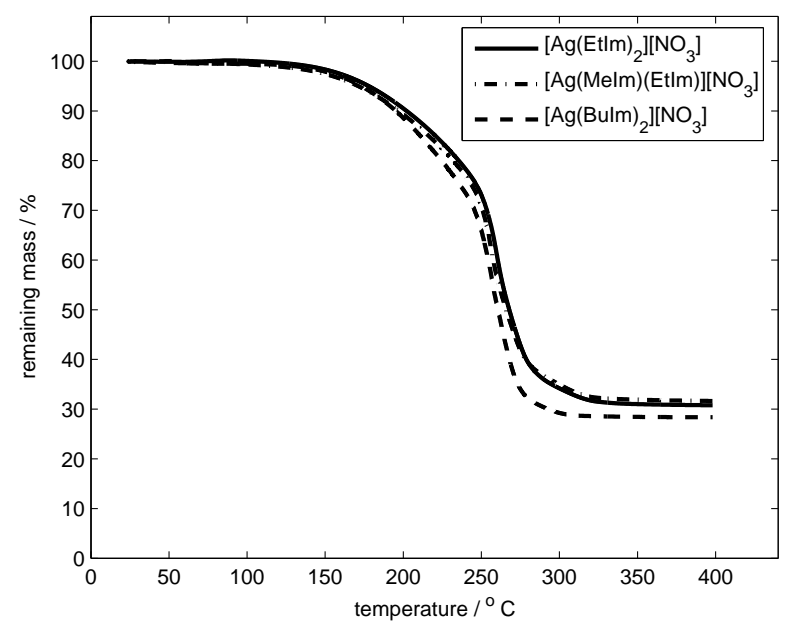

Fig. 6 Thermogravimetrical analysis (heating rate: $5{ }^{\circ} \mathrm{C} \mathrm{min} .{ }^{-1}$ in an argon atmosphere) for $\left[\mathrm{Ag}(\mathrm{EtIm})_{2}\right]\left[\mathrm{NO}_{3}\right]$,

$[\mathrm{Ag}(\mathrm{MeIm})(\mathrm{EtIm})]\left[\mathrm{NO}_{3}\right]$ and $\left[\mathrm{Ag}(\mathrm{BuIm})_{2}\right]\left[\mathrm{NO}_{3}\right]$.

table it is clear that the decomposition of the liquids to $\mathrm{Ag}_{2} \mathrm{O}$ is the most likely reaction path. This means that the liquids do not simply lose their imidazole ligands, but that the nitrate ion reacts as well at elevated temperatures.

One of the main reasons for the popularity of ionic liquids with fluorinated anions such as $\left[\mathrm{Tf}_{2} \mathrm{~N}\right]^{-},\left[\mathrm{PF}_{6}\right]^{-}$or $\left[\mathrm{BF}_{4}\right]^{-}$ is their low viscosity compared to ionic liquids with nonfluorinated anions. Therefore, we measured the viscosity of our liquids at several temperature to test whether they are low enough for practical applications. The results are given in Table 2 and plotted in Fig. 7. The viscosity of $\left[\mathrm{Ag}(\mathrm{BuIm})_{2}\right]\left[\mathrm{NO}_{3}\right]$ was only measured at three temperatures due to the higher melting point of this ionic liquid. When plotted as $\ln \eta$ vs $T^{-1}$, the data should be linear if the viscosity follows the Arrhenius equation

$$
\eta=\eta_{\infty} \exp \left(\frac{E_{a}}{\mathrm{R} T}\right)
$$

with $\eta_{\infty}$ the viscosity at infinite temperature, $T$ the absolute temperature, $E_{a}$ the activation energy and R the gas constant. From Fig. 7, one can conclude that Arrhenius behavior is not followed over the entire temperature range. The measured data points are therefore fitted by the Vogel-Tamman-Fulcher (VTF) equation

$$
\eta=A \exp \left(\frac{B}{T-T_{0}}\right)
$$

This relationship between viscosity and temperature, with $A, B$ and $T_{0}$ the fitting parameters, is more appropriate for liquids that can be undercooled and/or have a glass transition. Such a fitting was done for $\left[\mathrm{Ag}(\operatorname{EtIm})_{2}\right]\left[\mathrm{NO}_{3}\right]$, 
Table 2 Viscosity $\eta$ (mPa s) of the three ionic liquids.

\begin{tabular}{rcccccc}
\hline Ionic liquid & $303 \mathrm{~K}$ & $313 \mathrm{~K}$ & $323 \mathrm{~K}$ & $333 \mathrm{~K}$ & $343 \mathrm{~K}$ & $353 \mathrm{~K}$ \\
\hline$\left[\mathrm{Ag}(\mathrm{EtIm})_{2}\right]\left[\mathrm{NO}_{3}\right]$ & 1080 & 448 & 208 & 110 & 64 & 40 \\
{$[\mathrm{Ag}(\mathrm{MeIm})(\mathrm{EtIm})]\left[\mathrm{NO}_{3}\right]$} & 1524 & 540 & 230 & 118 & 67 & 42 \\
{$\left[\mathrm{Ag}(\mathrm{BuIm})_{2}\right]\left[\mathrm{NO}_{3}\right]$} & & & & 256 & 147 & 87 \\
{$\left[\mathrm{Ag}(\mathrm{HeIm})_{2}\right]\left[\mathrm{NO}_{3}\right]$} & 2600 & 1006 & 471 & 265 & 146 & 90 \\
{$\left[\mathrm{Ag}(\mathrm{OcIm})_{2}\right]\left[\mathrm{NO}_{3}\right]$} & 1540 & 821 & 416 & 238 & 135 & 84 \\
\hline
\end{tabular}

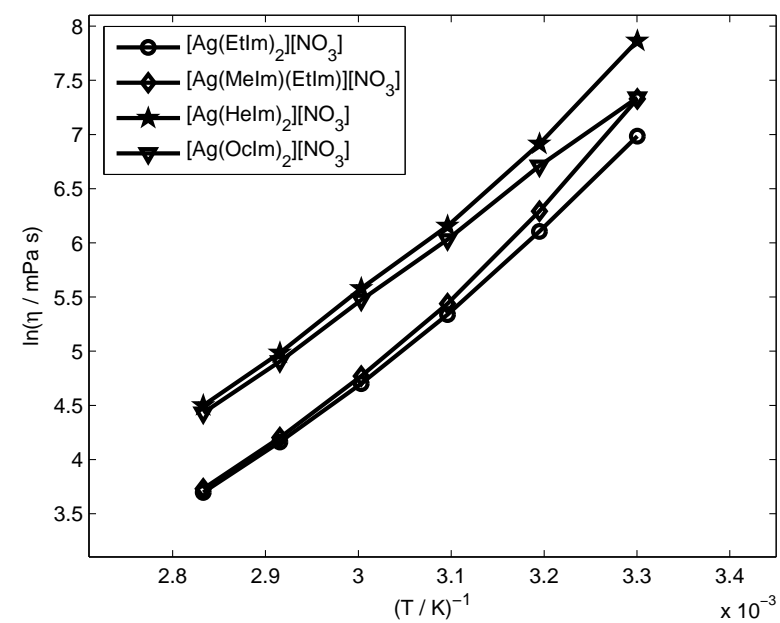

Fig. 7 Logarithm of the viscosities of $\left[\mathrm{Ag}(\mathrm{EtIm})_{2}\right]\left[\mathrm{NO}_{3}\right]$, $[\mathrm{Ag}(\mathrm{MeIm})(\mathrm{EtIm})]\left[\mathrm{NO}_{3}\right],\left[\mathrm{Ag}(\mathrm{HeIm})_{2}\right]\left[\mathrm{NO}_{3}\right]$ and $\left[\mathrm{Ag}(\mathrm{OcIm})_{2}\right]\left[\mathrm{NO}_{3}\right]$ measured at different temperatures.

$[\mathrm{Ag}(\mathrm{MeIm})(\mathrm{EtIm})]\left[\mathrm{NO}_{3}\right], \quad\left[\mathrm{Ag}(\mathrm{HeIm})_{2}\right]\left[\mathrm{NO}_{3}\right] \quad$ and $\left[\mathrm{Ag}(\mathrm{OcIm})_{2}\right]\left[\mathrm{NO}_{3}\right]$ and the resulting parameters are presented in Table 3. No fit was calculated for $\left[\mathrm{Ag}(\mathrm{BuIm})_{2}\right]\left[\mathrm{NO}_{3}\right]$ due to the higher melting point of this ionic liquid and the resulting lower number of data points. The fact that VTF-fitting

Table 3 Analysis of the viscosity data assuming VTF-behavior.

\begin{tabular}{rccc}
\hline Ionic liquid & $A(\mathrm{mPa} \mathrm{s})$ & $B(\mathrm{~K})$ & $T_{0}(\mathrm{~K})$ \\
\hline$\left[\mathrm{Ag}(\mathrm{EtIm})_{2}\right]\left[\mathrm{NO}_{3}\right]$ & 0.0215 & 1217 & 191 \\
{$[\mathrm{Ag}(\mathrm{MeIm})(\mathrm{EtIm})]\left[\mathrm{NO}_{3}\right]$} & 0.1030 & 790 & 221 \\
{$\left[\mathrm{Ag}(\mathrm{HeIm})_{2}\right]\left[\mathrm{NO}_{3}\right]$} & 0.4814 & 694 & 222 \\
{$\left[\mathrm{Ag}(\mathrm{OcIm})_{2}\right]\left[\mathrm{NO}_{3}\right]$} & 0.000035 & 4405 & 53 \\
\hline
\end{tabular}

gives a much better representation of the viscosity data than an Arrhenius plot indicates that they are undercooled liquids or glass formers. This VTF-behavior may be the reason why we could not obtain them as crystalline solids and why it was so difficult to obtain the BuIm liquid as a crystalline solid.

Fig. 8(a) shows the cyclic voltammogram for $\left[\mathrm{Ag}(\mathrm{EtIm})_{2}\right]\left[\mathrm{NO}_{3}\right]$ on a gold working electrode at 90
${ }^{\circ} \mathrm{C}$. It displays the typical characteristics for the electrodeposition and stripping of bulk metal: at negative potentials vs $\mathrm{Ag}$, the $\mathrm{Ag}^{+}$ion is extracted from the cation and reduced to silver metal. At positive potentials, this metallic silver layer is stripped. The voltammograms for $\left[\mathrm{Ag}(\mathrm{EtIm})_{2}\right]\left[\mathrm{NO}_{3}\right]$ and $\left[\mathrm{Ag}(\mathrm{BuIm})_{2}\right]\left[\mathrm{NO}_{3}\right]$ are not shown but show identical features.

The liquid $[\mathrm{Ag}(\mathrm{MeIm})(\mathrm{EtIm})]\left[\mathrm{NO}_{3}\right]$ was also characterized by QCM. Fig. 9 shows the mass $m_{q c m}$ experimentally measured by the QCM and the mass $m_{t h}$ theoretically calculated by Faraday's law:

$$
m_{t h}=\frac{M}{\mathrm{~F} n} \int_{0}^{t} i \mathrm{~d} t
$$

with $M$ the atomic mass of silver, $n$ the number of exchanged electrons, $\mathrm{F}$ the Faraday constant and $t$ the time needed to complete one cycle of the voltammogram (same as shown in Fig. 8(a)). The mass starts to increase as soon as the deposition potential becomes negative. For increasing overpotentials, the deposition rate increases in accordance with the cyclic voltammogram and the deposited mass reaches a maximum when the potential crosses again the $0.0 \mathrm{~V}$ mark. Hereafter the measured mass decreases as the deposited silver is dissolving. At the end of the cycle, the mass is back at the zero line indicating that all deposited silver is removed from the electrode proving that the electrodeposition of silver from $[\mathrm{Ag}(\mathrm{MeIm})(\mathrm{EtIm})]\left[\mathrm{NO}_{3}\right]$ is reversible. A comparison of $m_{t h}$ and $m_{q c m}$ shows that $m_{q c m}$ is slightly lower than $m_{t h}$ : the current efficiency of the process turned out to be $97 \%$. The reversibility of the process permits to use a sacrificial silver anode during electroplating because the $\mathrm{CV}$ and QCM experiments indicate that silver is electrochemically soluble in the electrolyte. The ligands that are liberated diffuse away from the electrode towards the bulk of the electrolyte and do not participate in the electrochemical reactions.

Potential scans that show which current densities can be achieved in electroplating are more important than the cyclic voltammograms. These scans are plotted in Fig. 8(b). $\left[\mathrm{Ag}(\mathrm{EtIm})_{2}\right]\left[\mathrm{NO}_{3}\right]$ and $[\mathrm{Ag}(\mathrm{MeIm})(\mathrm{EtIm})]\left[\mathrm{NO}_{3}\right]$ can achieve a similar current density of about $-12 \mathrm{~A} \mathrm{dm}^{-2}$. This was to be expected due their almost identical viscosities at higher temperatures and therefore similar mass transport. The current density that can be applied in $\left[\mathrm{Ag}(\mathrm{BuIm})_{2}\right]\left[\mathrm{NO}_{3}\right]$ is much 


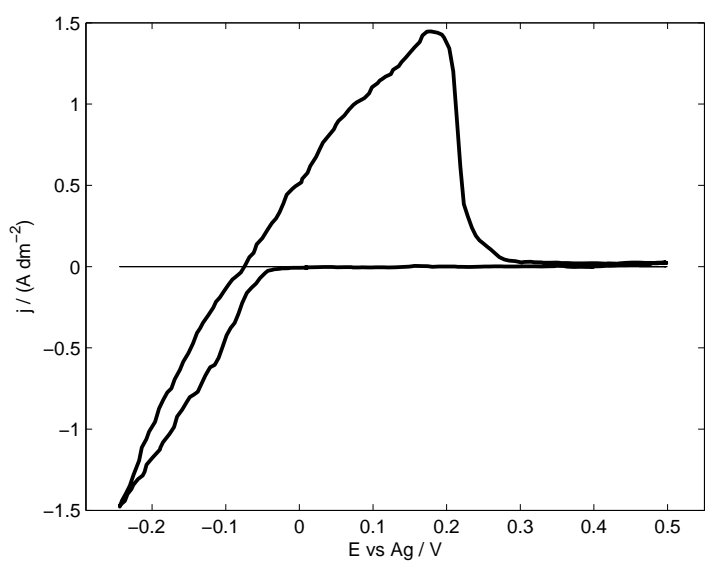

(a)

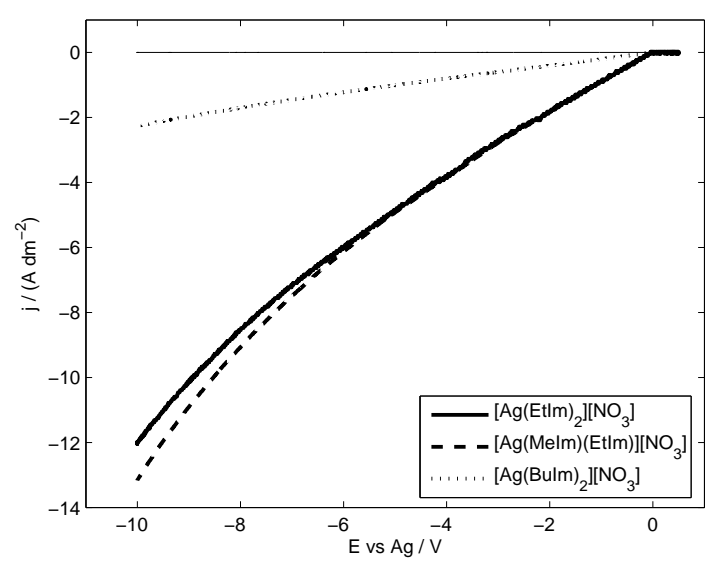

(b)

Fig. 8 (a) Cyclic voltammogram ( $i R$ corrected) of $[\mathrm{Ag}(\mathrm{MeIm})(\mathrm{EtIm})]\left[\mathrm{NO}_{3}\right]$ at $90^{\circ} \mathrm{C}$ and (b) potential scans from $\left[\mathrm{Ag}(\mathrm{EtIm})_{2}\right]\left[\mathrm{NO}_{3}\right],[\mathrm{Ag}(\mathrm{MeIm})(\mathrm{EtIm})]\left[\mathrm{NO}_{3}\right]$ and $\left[\mathrm{Ag}(\mathrm{BuIm})_{2}\right]\left[\mathrm{NO}_{3}\right]$ on a Au working electrode. The scan rate was $50 \mathrm{mV} \mathrm{s}^{-1}$.

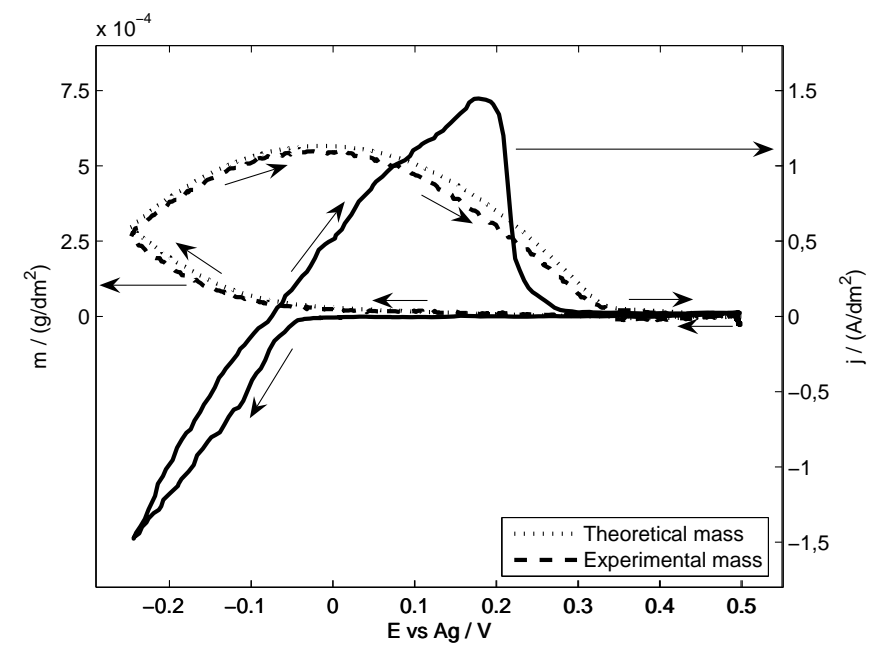

Fig. 9 Mass of silver deposited from $[\mathrm{Ag}(\mathrm{MeIm})(\mathrm{EtIm})]\left[\mathrm{NO}_{3}\right]$ at 90 ${ }^{\circ} \mathrm{C}$ measured by QCM $\left(m_{q c m}\right)$ and by Faraday's law $\left(m_{t h}\right)$ during cyclic voltammetry.

smaller: only $-2 \mathrm{~A} \mathrm{dm}^{-2}$. This can again be attributed to the viscosity which is more than twice as high compared to that of the two other ionic liquids because of the longer alkyl chains on the imidazole ligand. The currents that can be achieved in the three liquids reported in this paper are lower than what can be attained in $\left[\mathrm{Ag}(\mathrm{MeCN})_{4}\right]_{2}\left[\mathrm{Ag}\left(\mathrm{Tf}_{2} \mathrm{~N}\right)_{3}\right],{ }^{25}$ but these liquids are cheaper due to the presence of $\left[\mathrm{NO}_{3}\right]^{-}$and offer higher thermal stability.

The three liquid metal salts were also used for electrodeposition. The resulting deposits are shown in Fig. 10 (and ESI $\dagger$ ): they were made at current densities of -1 and $-5 \mathrm{~A} \mathrm{dm}^{2}$, except for $\left[\mathrm{Ag}(\mathrm{BuIm})_{2}\right]\left[\mathrm{NO}_{3}\right]$ in which only $-1 \mathrm{~A} \mathrm{dm}^{-2}$ was applied. All five deposits are of a good morphology: they are smooth, completely cover the substrate and are free of cracks. A typical EDX spectrum of the deposits is shown in the ESI $†$. No elements beside silver are detected. There are no indications for the decomposition of the ligands or the nitrate ion.

Since SEM micrographs can only give an approximate idea of the morphologies' roughness, the deposits were examined with AFM to gather quantitative data. These scans and roughness profiles are presented in Fig. 11 (and ESI $\dagger$ ). The values for $R_{q}$, with $R_{q}$ defined as

$$
R_{q}=\sqrt{\frac{1}{L} \int_{0}^{L} h^{2}(l) \mathrm{d} l}
$$

are given in table 4. The information collected by AFM corresponds with the views from the SEM micrographs. The silver layers deposited at $-1 \mathrm{~A} \mathrm{dm}^{-2}$ have the lowest surface roughness. With an $R_{q}$ value of $39 \mathrm{~nm}$, the deposit from $\left[\mathrm{Ag}(\mathrm{BuIm})_{2}\right]\left[\mathrm{NO}_{3}\right]$ is slightly less smooth than those 


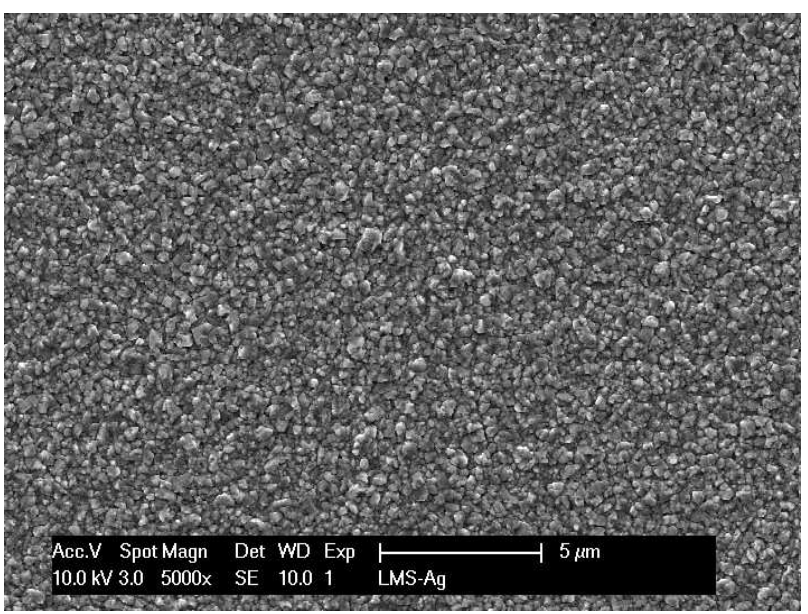

Fig. 10 SEM micrograph of silver a deposit from

$\left[\mathrm{Ag}(\mathrm{EtIm})_{2}\right]\left[\mathrm{NO}_{3}\right]$ on a $\mathrm{Au}$ working electrode at $90{ }^{\circ} \mathrm{C}$ obtained at $-1 \mathrm{~A} \mathrm{dm}^{-2}$, the theoretical thickness is $1 \mu \mathrm{m}$.

from $\left[\mathrm{Ag}(\mathrm{EtIm})_{2}\right]\left[\mathrm{NO}_{3}\right]$ and $[\mathrm{Ag}(\mathrm{MeIm})(\mathrm{EtIm})]\left[\mathrm{NO}_{3}\right]$ whose roughness is identical, taking the standard deviation into account. At $-5 \mathrm{~A} \mathrm{dm}^{-2}$, these two liquid metal salts give deposits with differing roughnesses of $47 \mathrm{~nm}$ and $62 \mathrm{~nm}$, respectively. The different roughnesses are also clear from the

Table $4 R_{q}$ values and roughness ranges for deposits from different ionic liquids on a $\mathrm{Au}$ working electrode at $90{ }^{\circ} \mathrm{C}$ obtained at -1 and $-5 \mathrm{~A} \mathrm{dm}^{-2}$.

\begin{tabular}{rcc}
\hline Ionic liquid & $\begin{array}{c}R_{q} \\
\mathrm{~nm}\end{array}$ & $\begin{array}{c}\text { range } \\
\mathrm{nm}\end{array}$ \\
\hline & \multicolumn{2}{c}{$-1 \mathrm{~A} \mathrm{dm}^{-2}$} \\
{$\left[\mathrm{Ag}(\mathrm{EtIm})_{2}\right]\left[\mathrm{NO}_{3}\right]$} & $29 \pm 1$ & 224 \\
{$[\mathrm{Ag}(\mathrm{MeIm})(\mathrm{EtIm})]\left[\mathrm{NO}_{3}\right]$} & $27 \pm 2$ & 234 \\
{$\left[\mathrm{Ag}(\mathrm{BuIm})_{2}\right]\left[\mathrm{NO}_{3}\right]$} & $39 \pm 4$ & 313 \\
\hline & \multicolumn{2}{c}{$-5 \mathrm{~A} \mathrm{dm}^{-2}$} \\
{$\left[\mathrm{Ag}(\mathrm{EtIm})_{2}\right]\left[\mathrm{NO}_{3}\right]$} & $47 \pm 4$ & 431 \\
{$[\mathrm{Ag}(\mathrm{MeIm})(\mathrm{EtIm})]\left[\mathrm{NO}_{3}\right]$} & $62 \pm 12$ & 678 \\
\hline
\end{tabular}

section cuts in Fig. 11(f). The difference of the highest and the lowest point, as measured by AFM, of the deposited silver layers is 224, 234 and $313 \mathrm{~nm}$ for $\left[\mathrm{Ag}(\mathrm{EtIm})_{2}\right]\left[\mathrm{NO}_{3}\right]$, $[\mathrm{Ag}(\mathrm{MeIm})(\mathrm{EtIm})]\left[\mathrm{NO}_{3}\right]$ and $\left[\mathrm{Ag}(\mathrm{BuIm})_{2}\right]\left[\mathrm{NO}_{3}\right]$, respectively. This proves once more that $\left[\mathrm{Ag}(\mathrm{BuIm})_{2}\right]\left[\mathrm{NO}_{3}\right]$ leads to slightly rougher deposits than the other two liquid metal salts.

\section{Conclusions}

Eight silver compounds with $\mathrm{N}$-alkylimidazole ligands and $\left[\mathrm{NO}_{3}\right]^{-}$as anions have successfully been synthesized and characterized. They are all low-melting ionic liquids and for four compounds the melting point is even below room temperature. These liquid metal salts are cheaper than the $\left[\mathrm{Tf}_{2} \mathrm{~N}\right]^{-}$ equivalent due to the absence of fluorine in the structure. The compounds with a low viscosity were further characterized and their thermal stability was tested by TGA. For all liquids, it was high enough for the liquids to be used at $90{ }^{\circ} \mathrm{C}$ for electrochemical purposes. The current densities that can be achieved in these liquids depended on the viscosity and the resulting silver deposits were of a high quality.

\section{Acknowledgements}

The authors acknowledge financial support by the FWOFlanders (Research Community "Ionic Liquids" and research project G0B9613N) and by the IWT-Flanders (SBO-project IWT 80031 "MAPIL"). The authors also thank the Hercules Foundation for supporting the purchase of the diffractometer through project AKUL/09/0035. Support by IoLiTec (Heilbronn, Germany) and The Dow Chemical Company is also acknowledged. The authors thank Johan Snauwaert for his kind help with the AFM-experiments.

\section{References}

1 S. A. Forsyth, J. M. Pringle and D. R. MacFarlane, Aust. J. Chem, 2004, 57, 113 .

2 F. Endres, ChemPhysChem, 2002, 3, 144.

3 A. P. Abbott and K. J. McKenzie, Phys. Chem. Chem. Phys., 2006, 8, 4265.

4 M.-J. Deng, P.-Y. Chen, T.-I. Leong, I.-W. Sun, J.-K. Chang and W.-T. Tsai, Electrochem. Commun., 2008, 10, 213.

5 D.-X. Zhuang, M.-J. Deng, P.-Y. Chen and I.-W. Sun, J. Electrochem. Soc., 2008, 155, D575.

6 M.-J. Deng, I.-W. Sun, P.-Y. Chen, J.-K. Chang and W.-T. Tsai, Electrochim. Acta, 2008, 53, 5812.

7 T.-I. Leong, I.-W. Sun, M.-J. Deng, C.-M. Wu and P.-Y. Chen, J. Electrochem. Soc., 2008, 155, F55.

8 P. Nockemann, B. Thijs, S. Pittois, J. Thoen, C. Glorieux, K. Van Hecke, L. Van Meervelt., B. Kirchner and K. Binnemans, J. Phys. Chem. B, 2006, 110, 20978.

9 P. Nockemann, M. Pellens, K. Van Hecke, L. Van Meervelt, J. Wouters, B. Thijs, E. Vanecht, T. N. Parac-Vogt, H. Mehdi, S. Schaltin, J. Fransaer, S. Zahn, B. Kirchner and K. Binnemans, Chem. Eur. J., 2010, 16, 1849.

10 I. J. B. Lin and C. S. Vasam, J. Organomet. Chem., 2005, 690, 3498.

11 C. Chiappe and M. Malvaldi, Phys. Chem. Chem. Phys., 2010, 12, 11191.

12 H. M. A. Abood, A. P. Abbott, A. D. Ballantyne and K. S. Ryder, Chem. Commun., 2011, 47, 3523.

13 T. M. Anderson, D. Ingersoll, A. J. Rose, C. L. Staiger and J. C. Leonard, Dalton Trans., 2010, 39, 8609.

14 H. D. Pratt III, J. C. Leonard, L. A. M. Steele, C. L. Staiger and T. M. Anderson, Inorg. Chim. Acta, 2013, 396, 78.

15 H. D. Pratt III, A. J. Rose, C. L. Staiger, D. Ingersoll and T. M. Anderson, Dalton Trans., 2011, 40, 11396.

16 C. L. Hussey and T. M. Laher, Inorg. Chem., 1981, 20, 4201.

17 S. Schaltin, P. Nockemann, B. Thijs, K. Binnemans and J. Fransaer, Electrochem. Solid-State Lett., 2007, 10, D104. 
18 S.-I. Hsiu, J.-F. Huang, I.-W. Sun, C.-H. Yuan and J. Shiea, Electrochim. Acta, 2002, 47, 4367.

19 R. E. Del Sesto, T. M. McCleskey, A. K. Burrell, G. A. Baker, J. D. Thompson, B. L. Scott, J. S. Wilkes and P. Williams, Chem. Commun., 2008, 447.

20 T. Peppel, A. Hinz and M. Köckerling, Polyhedron, 2013, 52, 482.

21 R. J. C. Brown, P. J. Dyson, D. J. Ellis and T. Welton, Chem. Commun., 2001, 1862.

22 Y. Qiao, J. Hu, H. Li, H. Li, Y. Hu, B. Feng and Z. Hou, J. Electrochem. Soc., 2010, 157, D124.

23 S. Schaltin, N. R. Brooks, K. Binnemans and J. Fransaer, J. Electrochem. Soc., 2011, 158, D21.

24 N. R. Brooks, S. Schaltin, K. Van Hecke, L. Van Meervelt, K. Binnemans and J. Fransaer, Chem. Eur. J., 2011, 17, 5054.

25 S. Schaltin, N. R. Brooks, L. Stappers, K. Van Hecke, L. Van Meervelt, K. Binnemans and J. Fransaer, Phys. Chem. Chem. Phys., 2012, 14, 1706.

26 N. R. Brooks, S. Schaltin, K. Van Hecke, L. Van Meervelt, J. Fransaer and K. Binnemans, Dalton Trans., 2012, 41, 6902.

27 D. Depuydt, N. R. Brooks, S. Schaltin, L. Van Meervelt, J. Fransaer and K. Binnemans, ChemPlusChem, 2013, 78, 578.

28 J.-F. Huang, H. Luo and S. Dai, J. Electrochem. Soc., 2006, 153, J9.
29 M. Iida, C. Baba, M. Inoue, H. Yoshida, E. Taguchi and H. Furusho, Chem. Eur. J., 2008, 14, 5047.

30 M. Iida, S. Kawakami, E. Syouna, H. Er and E. Taguchi, J. Colloid Interface Sci., 2011, 356, 630.

31 T. Inagaki and T. Mochida, Chem. Eur. J., 2012, 18, 8070.

32 T. Inagaki, T. Mochida, M. Takahashi, C. Kanadani, T. Saito and D. Kuwahara, Chem. Eur. J., 2012, 18, 6795.

33 S. Mori and T. Mochida, Organometallics, 2013, 32, 780.

34 S. Hamada and T. Mochida, J. Organomet. Chem., 2013, 725, 34.

35 Ionic liquids in synthesis, ed. P. Wasserscheid and T. Welton, Wiley-VCH, Weinheim, 2nd edn, 2008, p. 540.

36 CrysAlisPro, Agilent Technologies, Yarnton, UK, 2013.

37 G. M. Sheldrick, Acta Cryst., 2008, A64, 112.

38 A. V. Dolomanov, L. J. Bourhis, R. J. Gildea, J. A. K. Howard and H. Puschmann, J. Appl. Crystallogr., 2009, 42, 339.

39 A. Basile, A. I. Bhatt, A. P. O'Mullane and S. K. Bhargava, Electrochim. Acta, 2011, 56, 2895.

40 A. Bondi, J. Phys. Chem., 1964, 68, 441.

41 C. K. Lee, K.-M. Hsu, C.-H. Tsai, C. K. Lai and I. J. B. Lin, Dalton Trans., 2004, 1120. 

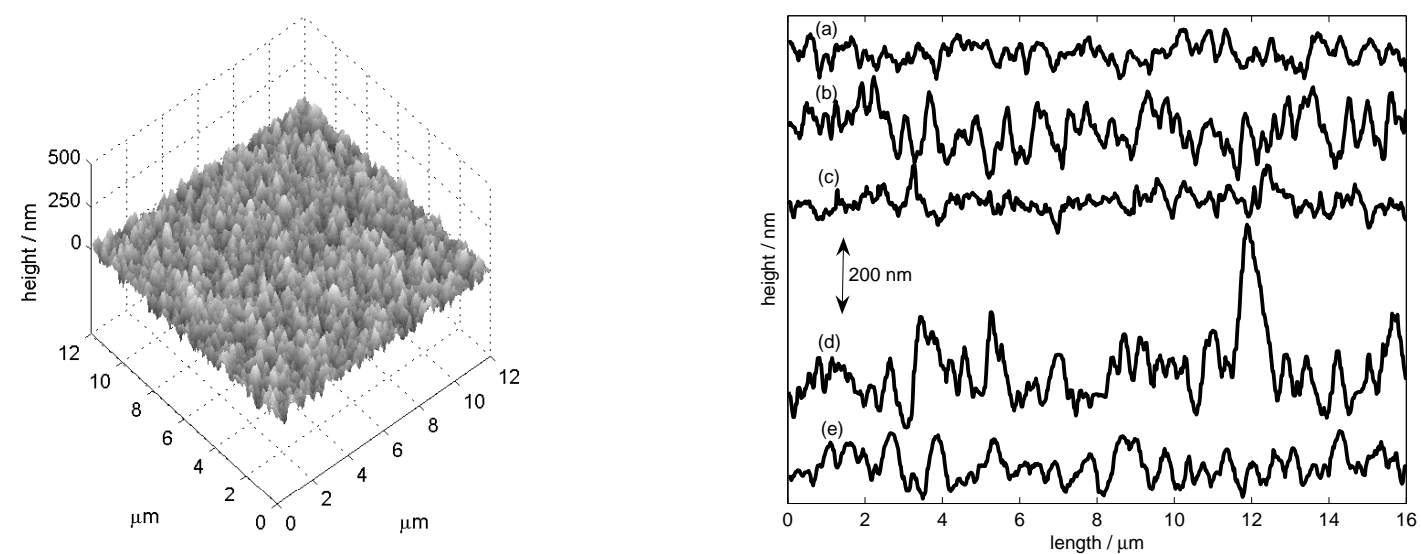

Fig. 11 Left: AFM image of a silver deposits from $\left[\mathrm{Ag}(\mathrm{EtIm})_{2}\right]\left[\mathrm{NO}_{3}\right]$ on a Au working electrode at $90{ }^{\circ} \mathrm{C}$ obtained at $-1 \mathrm{~A} \mathrm{dm}{ }^{-2}$. Right: roughness profiles of silver deposits from $\left[\mathrm{Ag}(\mathrm{EtIm})_{2}\right]\left[\mathrm{NO}_{3}\right](\mathrm{a}-\mathrm{b}),[\mathrm{Ag}(\mathrm{MeIm})(\mathrm{EtIm})]\left[\mathrm{NO}_{3}\right](\mathrm{c}-\mathrm{d})$ and $\left[\mathrm{Ag}(\mathrm{BuIm})_{2}\right]\left[\mathrm{NO}_{3}\right](\mathrm{e})$ on a $\mathrm{Au}$ working electrode at $90{ }^{\circ} \mathrm{C}$ obtained at $-1 \mathrm{~A} \mathrm{dm}^{-2}$ (a-c-e) and $-5 \mathrm{~A} \mathrm{dm}^{-2}$ (b-d). 